Valéria R. A. Pereira $\cdot$ Virginia M. B. Lorena

Mineo Nakazawa · Carlos F. Luna

Edimilson D. Silva · Antonio G. P. Ferreira

Marco Aurélio Krieger · Samuel Goldenberg

Milena B. P. Soares · Eridan M. Coutinho

Rodrigo Correa-Oliveira · Yara M. Gomes

\title{
Humoral and cellular immune responses in BALB/c and C57BL/6 mice immunized with cytoplasmic (CRA) and flagellar (FRA) recombinant repetitive antigens, in acute experimental Trypanosoma cruzi infection
}

Received: 11 January 2005 / Accepted: 24 February 2005 / Published online: 27 April 2005

(C) Springer-Verlag 2005

\begin{abstract}
In previous studies, cytoplasmic repetitive antigen (CRA) and flagellar repetitive antigen (FRA) proteins induced specific humoral and cellular immune responses in susceptible and resistant mice in the absence of Trypanosoma cruzi infection with a significant induction of the Interferon-gamma (IFN- $\gamma$ ) production in those animals. In this follow-up paper, the immunostimulatory and protective effects of these proteins were evaluated by immunizing with CRA or FRA antigens, $\mathrm{BALB} / \mathrm{c}$ and $\mathrm{C} 57 \mathrm{BL} / 6$ mice and challenging with a T. cruzi (Y strain). Both proteins induced humoral response with high levels of IgG isotypes as well as cellular immunity with high levels of IFN- $\gamma$ when compared to controls. However, the lymphocyte proliferative response was minimal. The survival rate at 30 days post-infection was significant in CRA $(60 \%)$ or FRA $(50 \%)$ - immunized $\mathrm{BALB} / \mathrm{c}$ mice and CRA
\end{abstract}

\footnotetext{
V. R. A. Pereira · V. M. B. Lorena · M. Nakazawa

C. F. Luna - E. M. Coutinho · Y. M. Gomes $(\bowtie)$

Centro de Pesquisas Aggeu Magalhães/FIOCRUZ,

Recife, PE, Brazil

E-mail: yara@cpqam.fiocruz.br

Tel.: + 55-81-21012559

Fax: + 55-81-34532449

R. Correa-Oliveira

Centro de Pesquisas René Rachou/FIOCRUZ,

Belo Horizonte, MG, Brazil
}

E. D. Silva · A. G. P. Ferreira

Bio-Manguinhos/FIOCRUZ, Salvador, Brazil

M. B. P. Soares

Centro de Pesquisas Gonçalo Moniz, Salvador, BA, Brazil

M. A. Krieger $\cdot$ S. Goldenberg

Instituto Oswaldo Cruz/FIOCRUZ, Rio de Janeiro, RJ, Brazil

M. A. Krieger · S. Goldenberg

Instituto de Biologia Molecular do Paraná/IBMP,

Curitiba, PR, Brazil
$(83.3 \%)$ - immunized C57BL/6 mice. Taken as a whole these findings indicate that CRA and FRA are immunogenic and potentially important for protective immunity.

\section{Introduction}

Chagas' disease, an infection caused by the protozoan parasite Trypanosoma cruzi, affects several million people in the American hemisphere (WHO 2002). Under natural conditions, $T$. cruzi is transmitted to humans by a haematophagous reduviid insect vector, which deposits its infective feces or urine on the skin of the host at the time of biting, this being the most significant route of transmission in endemic areas. However, T. cruzi may be transmitted to man by a number of alternative mechanisms (blood transfusion, organ transplantation, accidental laboratory infection, oral or congenital transmission (Gomes 1997). However, blood transfusion is the dominant means of transmission in non-endemic areas.

T. cruzi infections are associated with immunological and immunopathological reactions that may result from non-specific polyclonal activation (Kierszenbaum 1981; Minoprio et al. 1986) or supressive effects (Ramos et al. 1979; Kierszenbaum et al. 1980; Abrahamsohn and Coffman 1995). Experimental infection with $T$. cruzi induces cytokine production involved in the regulation of immune responses. Interferon-gamma (IFN- $\gamma$ ) has been demonstrated to be a protective cytokine against T. cruzi. Macrophages activated by IFN- $\gamma$ release reactive oxygen metabolites and nitric oxide (NO) (Vespa et al. 1994). In addition, the immune control of T. cruzi infection involves the participation of $\mathrm{CD}^{+}{ }^{+}$and $\mathrm{CD} 8^{+}$ T cells (Sher and Coffman 1992). Studies with CD4 and CD8 KO mice that are highly susceptible to the parasite 
showed the importance of both T-cell populations during naturally acquired immune responses to $T$. cruzi infections (Rottenberg et al. 1993).

Despite the importance of cellular immune responses, anti-parasite humoral responses also play a major role in resistance to T. cruzi infection (Brener and Krettli 1990). The major antibody isotypes involved in protection are IgG1 and IgG2 (Araújo et al. 1984; Takehara et al. 1981; Brodskyn et al. 1989). These findings showed the importance of the humoral and cellular immune responses in the control of parasitemia and mortality during $T$. cruzi infection.

Several recombinant antigens have been used to evaluate protective immune responses against $T$. cruzi infection (Taibi et al. 1995; Santori et al. 1996; PereiraChioccola et al. 1999; Millar et al. 2000; Schnapp et al. 2002). We have previously demonstrated the immunogenicity of cytoplasmic repetitive antigen (CRA) and flagellar repetitive antigen (FRA) recombinant proteins of $T$. cruzi by evaluating the humoral and cellular responses in uninfected susceptible (BALB/c) and resistant $(\mathrm{C} 57 \mathrm{BL} / 6)$ mice strains immunized with these proteins (Pereira et al. 2003a, 2003b, 2004). These antigens were able to elicit the production of specific IgG immunoglobulins. CRA induced predominantly the production of $\mathrm{IgG} 1$ and $\mathrm{IgG} 3$ isotypes in $\mathrm{BALB} / \mathrm{c}$ and $\mathrm{C} 57 \mathrm{BL} / 6$ mice, while FRA induced antibodies of the IgG1 isotype in BALB/c mice (Pereira et al. 2003a, 2003b). Cellular lymphoproliferative response was also observed in both mouse strains. Moreover, spleen cell cultures mainly from CRA-immunized C57BL/6 and FRA-immunized BALB/ $\mathrm{c}$ mice produced high levels of IFN- $\gamma$, indicating that these antigens brought about a significant up-regulation of the Th1-type immune response (Pereira et al. 2004).

In the present paper, the humoral and cellular responses in mice immunized with CRA or FRA recombinant antigens and challenged with the $\mathrm{Y}$ strain of $T$. cruzi were evaluated to detect a protective effect of theses antigens against host infection or spread of parasite infection within the host.

\section{Materials and methods}

Mice

Six- to eight-week-old BALB/c and C57BL/6 male mice from the Animal Breeding Center-Oswaldo Cruz Foundation (FIOCRUZ), Rio de Janeiro, Brazil, were used. The guidelines of the Ethical Committee for the use of experimental animals of the Fundação Oswaldo Cruz/FIOCRUZ (Ministry of Health, Brazil) were followed.

\section{Antigens}

CRA and FRA antigens were obtained as described by Krieger et al. (1992). Briefly, the genes encoding CRA and FRA were cloned and their expression induced using isopropyl- $\beta$-D-thiogalactoside (IPTG). After centrifugation, the proteins were purified by nickel affinity chromatography according to the supplier's directions (Qiagen).

Immunization and infection

Fifty mice of each strain (BALB/c and C57BL/6) were injected three times by subcutaneous route at 20-day intervals with $20 \mu \mathrm{g}$ and $12 \mu \mathrm{g}$ of CRA or FRA, respectively (equimolar doses), according to Pereira et al. (2004). Mice were infected intraperitoneally with $10^{4}$ blood-form trypomastigotes of the $\mathrm{Y}$ strain of T. cruzi, 3 weeks after the last immunization, as described by Gomes et al. (1999). Parasitemia was measured using Brener's technique (1962), from the fifth to the thirtieth day post-infection (d.p.i.). Dead mice were removed daily. The humoral and cellular immune responses were evaluated at 7, 14 and 30 d.p.i.

ELISA assay for measurement of murine $\mathrm{IgG}$ isotype serum levels

ELISA was performed as described by Pereira et al. (2003a). Briefly, microtiter plates (Nunc-Immuno Plates, MaxiSorp, 96 wells, Nalge Nunc International Corporation) were coated with $1 \mu \mathrm{g} / \mathrm{ml}$ of CRA or FRA $(100 \mu \mathrm{l} /$ well) diluted in $0.05 \mathrm{M} \mathrm{Na}_{2} \mathrm{CO}_{3}$ buffer, $\mathrm{pH} 9.6$ and incubated overnight at $4^{\circ} \mathrm{C}$. Mice serum $(100 \mu \mathrm{l})$ diluted 1:100 was added and incubated overnight. After washing, the plates were incubated with peroxidase-labelled rabbit antibodies to mouse immunoglobulins isotypes (antiIgG1, anti-IgG2a, anti-IgG2b, and anti-IgG3) and the reaction brought on by addition of orthophenyldiamineOPD and $\mathrm{H}_{2} \mathrm{O}_{2}$. The optical density (OD) was measured at $490 \mathrm{~nm}$ on a BioRad 3550 plate reader.

\section{Proliferation assay}

Spleens and inguinal lymph nodes were removed aseptically. Cell suspensions from CRA- or FRA-immunized and control mice (pools of three mice per group) were prepared and cultured in a 96-well plate at a density of $4 \times 10^{5}$ cell/well) in an RPMI-1640 supplemented with $10 \%$ of fetal calf serum, $2 \mathrm{mM}$ L-glutamine, $100 \mathrm{U} / \mathrm{ml}$ penicillin and $100 \mu \mathrm{g} / \mathrm{ml}$ streptomycin (Sigma) for $72 \mathrm{~h}$ at $37^{\circ} \mathrm{C}$ in $5 \% \mathrm{CO}_{2}$. The cultures were stimulated in the absence or the presence of CRA $(20 \mu \mathrm{g} / \mathrm{ml})$ or FRA $(12 \mu \mathrm{g} / \mathrm{ml})$ antigens, and with concanavalin A (Con A; $2.5 \mu \mathrm{g} / \mathrm{ml})$. Eighteen hours before harvesting, the plates were pulsed with $0.5 \mu \mathrm{Ci} /$ well with $\left[{ }^{3} \mathrm{H}\right] \mathrm{TdR}$ (Amersham Pharmacia, Little Chalfont, UK). Isotope incorporation was determined by liquid scintillation counting and the results were expressed as the arithmetic mean counts per minute (cpm) of triplicate sample \pm standard deviation (SD). 
Measurement of cytokine levels in splenocyte supernatants

Spleen cells $\left(10^{7}\right.$ cells/well $)$ were stimulated for $24 \mathrm{~h}$ with the same antigens and concentration used in proliferative assays. The levels of the cytokines IL-4, IL-10, TNF- $\alpha$ and IFN- $\gamma$ were measured using specific two-site ELISA according to the manufacturers suggested protocols. The antibody pairs used for the detection of IL-4 (detection limit $31.3 \mathrm{pg} / \mathrm{ml}$ ), IL-10 (detection limit $78 \mathrm{pg} / \mathrm{ml}$ ), TNF- $\alpha$ (detection limit $6.25 \mathrm{ng} / \mathrm{ml}$ ) and IFN- $\gamma$ (detection limit $156 \mathrm{pg} / \mathrm{ml}$ ) were purchased from R\&D Systems. All samples were assayed in duplicate and read at $405 \mathrm{~nm}$ on an automatic Bio-Rad 3550 ELISA plate reader. The concentrations were determined with reference to a standard curve.

\section{Morphological study}

Three infected mice from each group sacrificed after 7 , 14 and 30 d.p.i., as well as those which died spontaneously, were autopsied. Samples of heart and spleen were fixed in $10 \%$ neutral formalin, embedded in paraffin and sectioned at $5 \mu \mathrm{m}$. Sections were routinely stained with haematoxylin and eosin.

\section{Statistical analysis}

Data were analyzed using the following methods: Mann-Whitney $U$, Kaplan-Meier and Bonferroni tests were used to detect differences between the groups. SPSS v.8-Statistical Package for Social Sciences Incorporation, US and EXCEL (Microsoft, US) were the programs used. Values of $P<0.05$ were taken to be significant.

\section{Results}

Parasitemia and mice survival rates

The mean of parasites $/ 50$ microscopical fields of mice blood and survival rates are shown in Table 1. Parasitemia was lower in challenged C57BL/6 mice immunized with CRA and FRA recombinant antigens than in $\mathrm{BALB} / \mathrm{c}$ mice. In both strains, the peak of parasitemia was detected at 8 d.p.i., in a similar way as in control mice. The course of $T$. cruzi infection was equivalent, in all the groups, but the survival rates showed significant differences $(P<0.05)$ (Fig. 1). At 30 d.p.i. they were higher, in CRA $(60 \%)$ or FRA $(50 \%)$ - immunized BALB/c mice and in CRA $(83.3 \%)$ - immunized C57BL/6 mice, when compared to those seen in control mice. All infected BALB/c mice that were not previously immunized with the recombinant antigens died after challenge. However, $16.6 \%$ of the control C57BL/6 mice survived.

\section{Production of $\mathrm{IgG}$ isotypes}

Trypanosoma cruzi infection in BALB/c and C57BL/6 immunized mice increased the levels of IgG isotypes. At 7 d.p.i., the levels of all $\operatorname{IgG}$ isotypes ( $\operatorname{IgG} 1, \operatorname{IgG} 2 \mathrm{a}$, $\mathrm{IgG} 2 \mathrm{~b}$ and $\mathrm{IgG} 3)$ in $\mathrm{CRA}$-immunized $\mathrm{BALB} / \mathrm{c}$ and C57BL $/ 6$ mice were higher $(P<0.05)$ when compared to the control mice (Fig. 2a, 3a). In CRA or FRA-immunized $\mathrm{BALB} / \mathrm{c}$ mice results were not significant even at 30 d.p.i. (Fig. 2b, d). Figure $3 b$ also shows the ELISA used for detection of antibodies against CRA in C57BL/ 6 , results after 30 d.p.i. being similar to previous time points. All IgG subclasses of FRA-immunized BALB/c mice increased significantly $(P<0.05)$ at 7 d.p.i. (Fig. 2c). In contrast, in infected FRA-immunized $\mathrm{C} 57 \mathrm{BL} / 6$ only the $\mathrm{IgG} 2 \mathrm{~b}$ isotype produced increased

Table 1 Parasitemia and survival rates in mice acutely infected with the Y strain of T. cruzi 30 days post-infection

\begin{tabular}{|c|c|c|c|c|c|c|}
\hline \multirow[t]{2}{*}{ Variables } & \multicolumn{3}{|l|}{$\mathrm{BALB} / \mathrm{c}$} & \multicolumn{3}{|l|}{$\mathrm{C} 57 \mathrm{BL} / 6$} \\
\hline & Control & CRA & FRA & Control & CRA & FRA \\
\hline \multicolumn{7}{|l|}{ Parasitemia $^{\mathrm{a}}$} \\
\hline 5 d.p.i. & $8.25 \pm 2.2$ & $2.8 \pm 1.2$ & $7.5 \pm 2.5$ & $1.8 \pm 0.6$ & $0.3 \pm 0.2$ & $1.3 \pm 1.3$ \\
\hline 6 d.p.i. & $2.75 \pm 0.8$ & $1.6 \pm 0.2$ & $2.75 \pm 0.9$ & $2.2 \pm 0.9$ & $0.7 \pm 0.3$ & $1.2 \pm 1.2$ \\
\hline 7 d.p.i. & $90 \pm 23$ & $41.8^{\mathrm{b}} \pm 9.8$ & $93.5 \pm 29.9$ & $9.5 \pm 2.3$ & $2.2^{\mathrm{b}, \mathrm{c}} \pm 1.2$ & $10.5 \pm 10.5$ \\
\hline 8 d.p.i. & $152.7 \pm 53$ & $54.4 \pm 10.7$ & $84.5 \pm 22.9$ & $2.5 \pm 9.8$ & $17 \pm 2.9$ & $24.3 \pm 24.3$ \\
\hline 9 d.p.i. & $14 \pm 3.4$ & $18.6^{\mathrm{c}} \pm 6.5$ & $5 \pm 1.5$ & $2.5 \pm 1$ & $2.2 \pm 0.4$ & $3.5 \pm 3.5$ \\
\hline 14 d.p.i. & $44.5 \pm 7$ & $22.2 \pm 6$ & $24 \pm 10.2$ & $3.8 \pm 1.2$ & $4.2 \pm 1.5$ & $8.8 \pm 8.7$ \\
\hline 17 d.p.i. & & $18.5 \pm 4.9$ & $30 \pm 10.4$ & $9.4 \pm 2.7$ & $3.8 \pm 2.7$ & $13.8 \pm 1.62$ \\
\hline 21 d.p.i. & d & $32 \pm 14.3$ & $15.5 \pm 3.5$ & $6.8 \pm 2.9$ & $4 \pm 2.9$ & $6 \pm 1$ \\
\hline 30 d.p.i. & d & $17 \pm 10$ & $14 \pm 6$ & $10 \pm 0$ & $2 \pm 0$ & $4 \pm 1$ \\
\hline Survival $^{\mathrm{e}}(\%)$ & 0 & 60 & 50 & 16.6 & 83.3 & 16.6 \\
\hline
\end{tabular}


Fig. 1 Survival rate of CRA(a) and FRA- (b) immunized $\mathrm{BALB} / \mathrm{c}$ and CRA (c) and FRA (d) immunized C57BL/6 during infection with strain Y T. cruzi. Groups of five animals were analysed
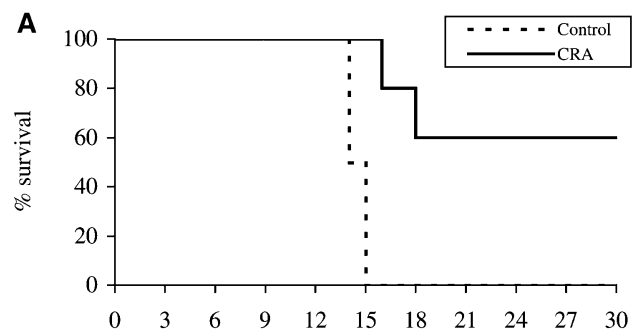

days post-infection

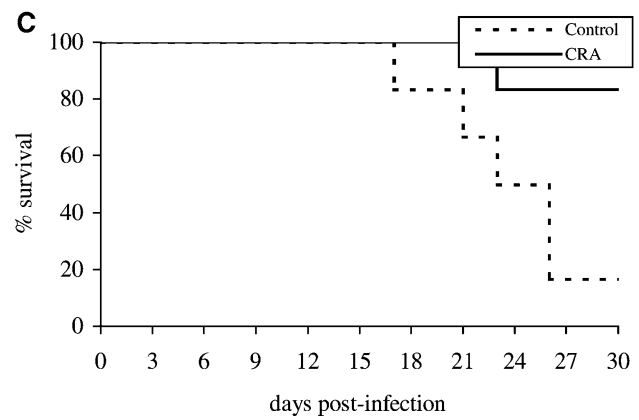

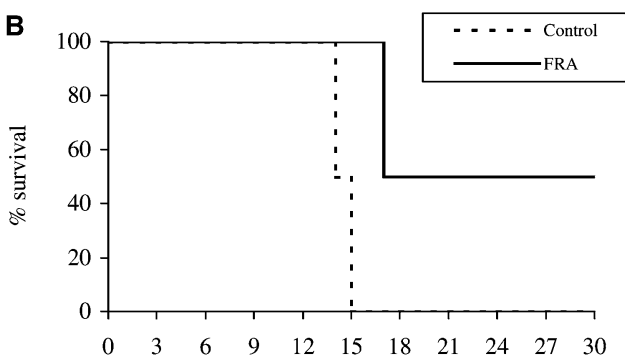

days post-infection

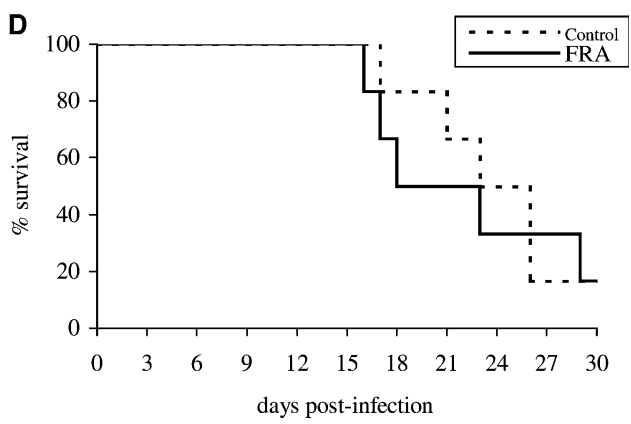

(Fig. 3c). Significant differences did not occur between the $\mathrm{IgG}$ isotypes at 30 d.p.i. (Fig. 3d).

\section{Cytokines production}

Supernatants obtained from spleen cells cultures of both the mouse strains showed the highest levels of IFN- $\gamma$ at 30 d.p.i., as compared to controls (Fig. 4). In BALB/c mice they increased significantly after immunization with both the recombinant antigens (CRA and FRA) (Fig. 4a, b). In C57BL/6 mice, however, significant amounts of IFN- $\gamma$ were produced 30 d.p.i. upon FRA immunization, but the CRA antigen did not induce the same result (Fig. 4d, c). Although IL-4, IL-10 and TNF- $\alpha$ were

Fig. 2 Subclasses of antigen specific immunoglobulins in the sera of CRA (a, 7 d.p.i., b, 30 d.p.i) and FRA (c, 7 d.p.i., d, 30 d.p.i.) immunized $\mathrm{BALB} / \mathrm{c}$ infected mice. The results are expressed as the average of 5 mice \pm SD
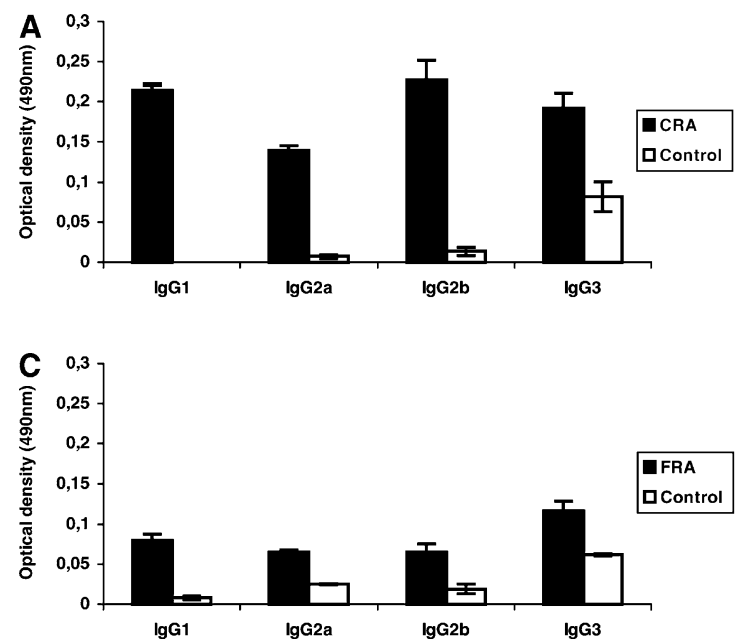

detected in the supernatant of cultures, their levels were not different from those detected in controls.

\section{Lymphocyte proliferation assays}

Cellular proliferation was minimal or undetectable during the experimental infection. Spleen cells from infected $\mathrm{BALB} / \mathrm{c}$ and $\mathrm{C} 57 \mathrm{BL} / 6$ mice did not proliferate when stimulated in vitro with CRA, FRA, or Con A, indicating that the stimulus responsiveness of these cells was suppressed. Lymph node cells of both strains of mice responded only to Con A at 7 d.p.i.. After 14 d.p.i., the proliferation of lymph node cells was null.

\section{Morphological study}

At 7 d.p.i, no heart lesions were seen in CRA- or FRAimmunized BALB/c and C57BL/6 mice. Hypercellular-
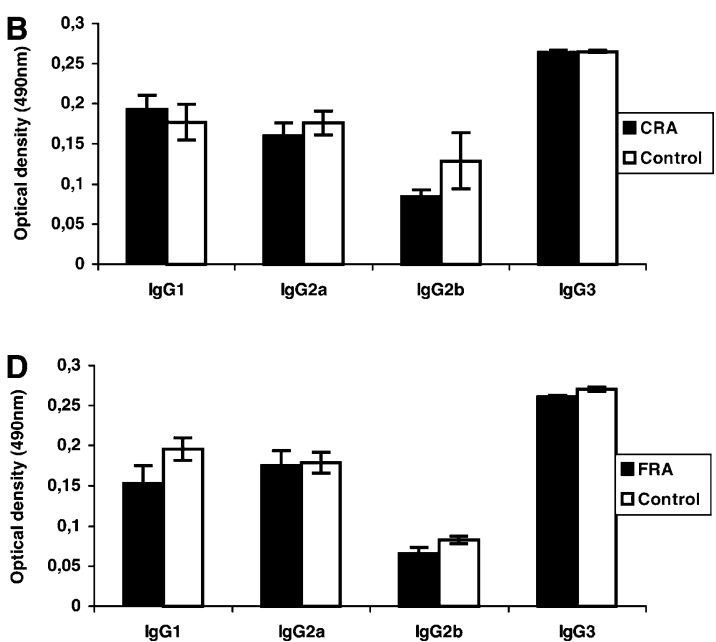

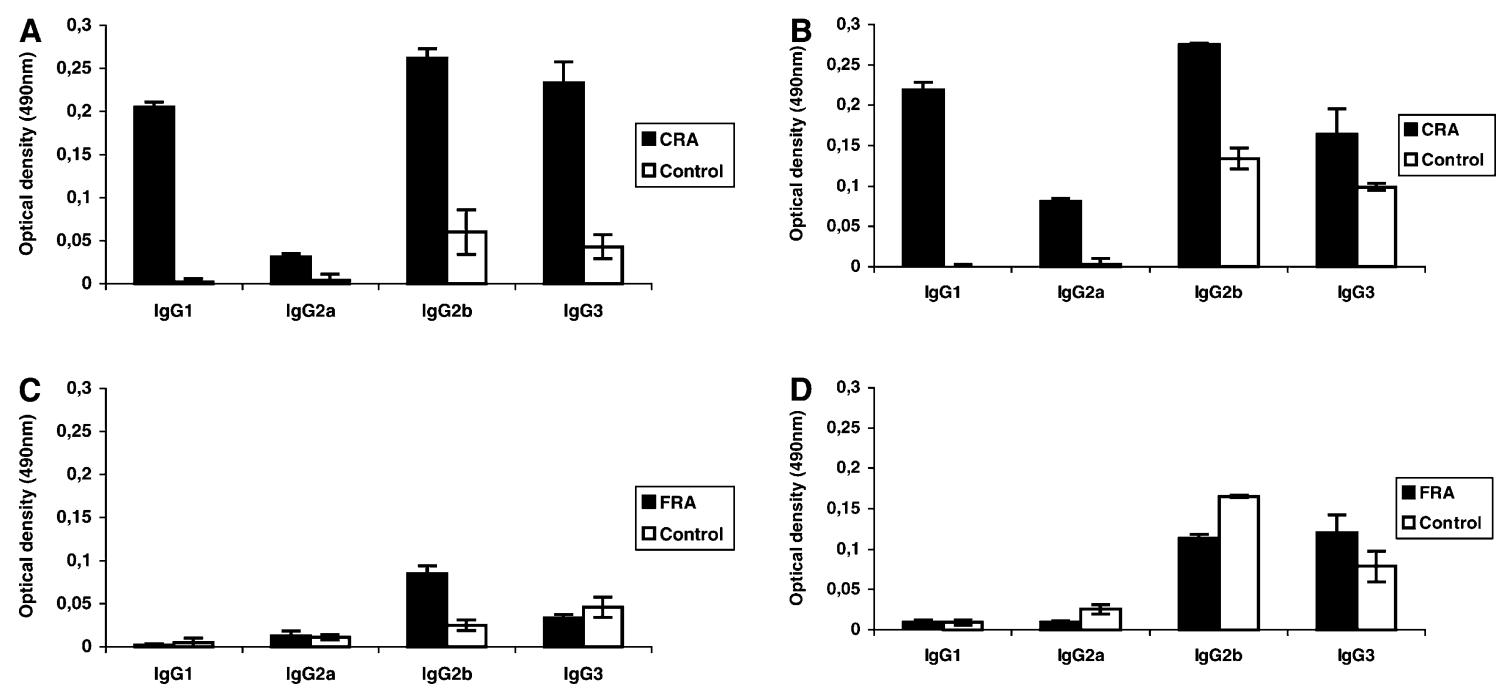

Fig. 3 Subclasses of antigen specific immunoglobulins in the sera of CRA (a, 7 d.p.i., b, 30 d.p.i) and FRA (c, 7 d.p.i., d, 30 d.p.i.) immunized $\mathrm{C} 57 \mathrm{BL} / 6$ infected mice. The results are expressed as the average of 5 mice $\pm \mathrm{SD}$

Fig. 4 IFN- $\gamma$ produced by $\mathrm{T}$ cells from CRA (a) or FRA (b) -immunized infected $\mathrm{BALB} / \mathrm{c}$ mice and CRA (c) or FRA (d) -immunized infected C57BL/6 mice. Spleen cells were cultured with CRA $(20 \mu \mathrm{g} / \mathrm{ml})$ or FRA $(12 \mu \mathrm{g} / \mathrm{ml})$ and Con A $(2.5 \mu \mathrm{g} / \mathrm{ml})$. Supernatants were collected 30 days post-infection with the $\mathrm{Y}$ strain of $T$. cruzi. Each bar represents the average values \pm standard deviations obtained from duplicate cultures
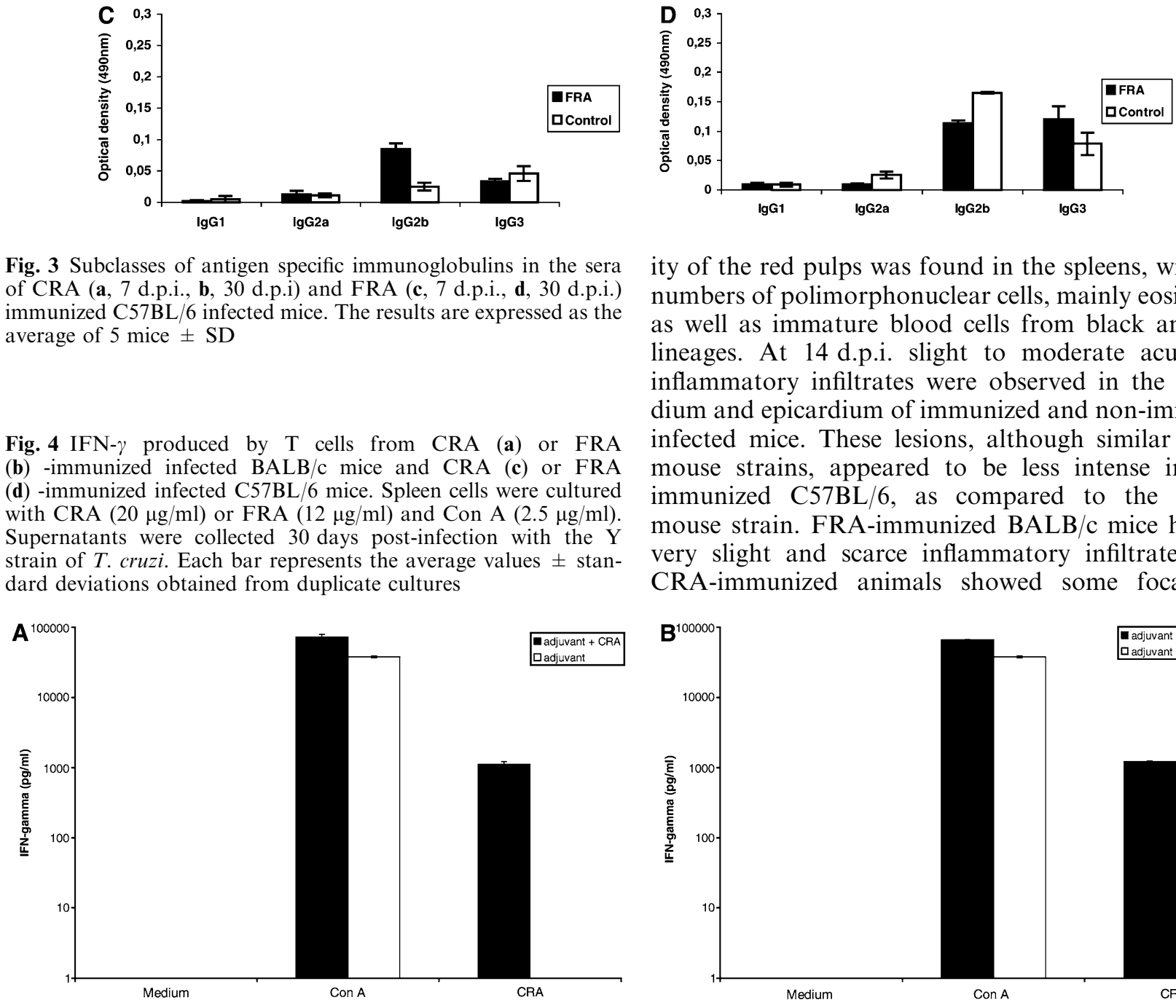

ity of the red pulps was found in the spleens, with great numbers of polimorphonuclear cells, mainly eosinophils, as well as immature blood cells from black and white lineages. At 14 d.p.i. slight to moderate acute focal inflammatory infiltrates were observed in the myocardium and epicardium of immunized and non-immunized infected mice. These lesions, although similar in both mouse strains, appeared to be less intense in CRAimmunized $\mathrm{C} 57 \mathrm{BL} / 6$, as compared to the $\mathrm{BALB} / \mathrm{c}$ mouse strain. FRA-immunized BALB/c mice had only very slight and scarce inflammatory infiltrates, while CRA-immunized animals showed some focal atrial
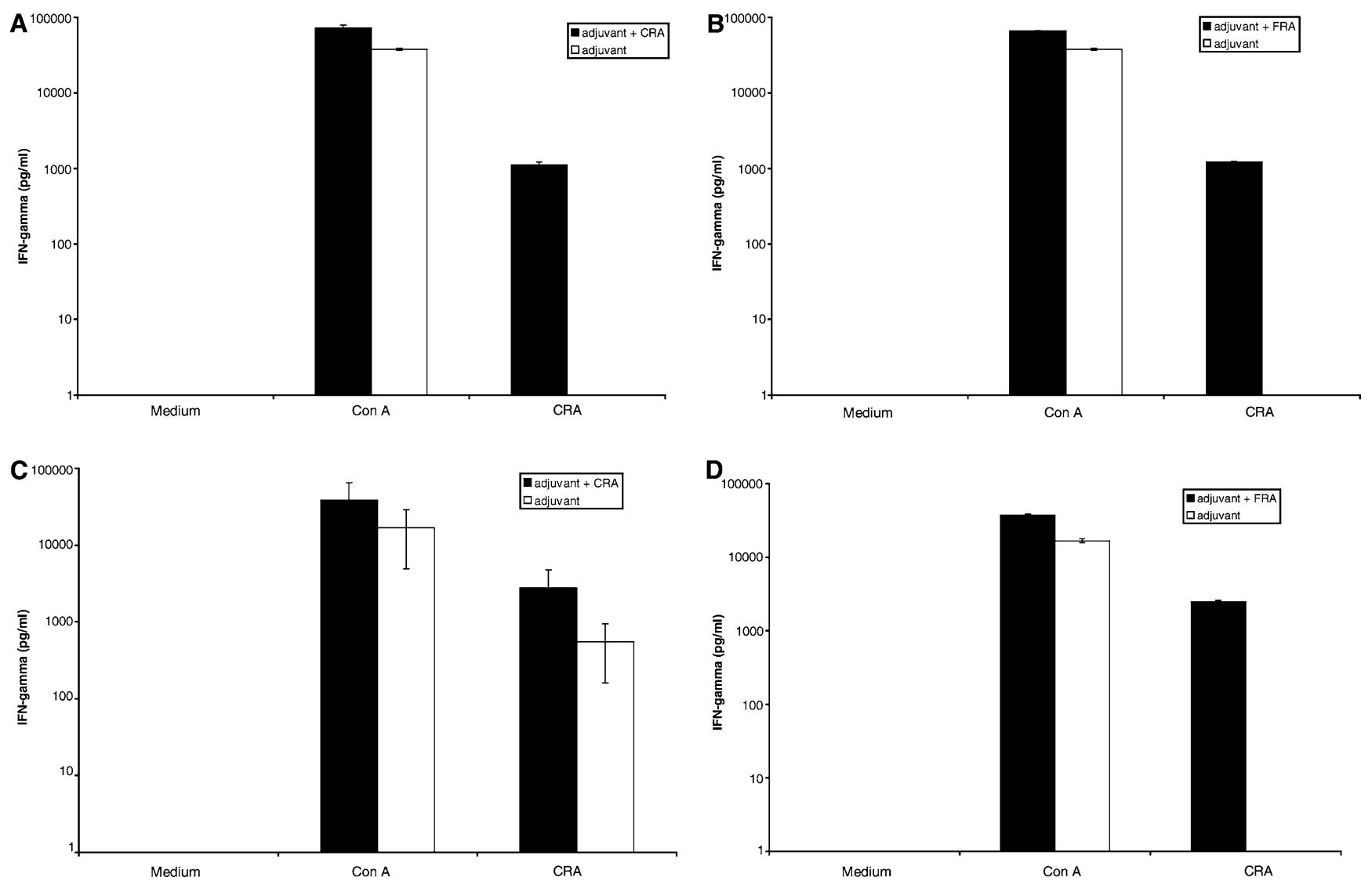
inflammation. At 30 d.p.i., less severe cardiac and splenic inflammatory lesions could still be detected in control animals, but only a few foci of intersticial myocarditis and epicarditis were observed in CRA- and FRA-immunized BALB/c mice. In FRA-immunized C57BL/6 mice, cardiac lesions were negligible.

\section{Discussion}

The successful survival of protozoan pathogens such as $T$. cruzi depends mainly on evading the host immune system by, for example, increasing phagocytic activity or anergy of $T$ cells (Zambrano-Villa et al. 2002). Besides, parasitic infections frequently result in high $\mathrm{CD} 4^{+} \mathrm{T}$ cell responses characterized by Th1 or Th2 cytokine production profiles. This polarization may be brought about by different factors of pathogen-antigen-presenting-cell interaction (Jankovic et al. 2001). In order to evaluate which are the polarizing cytokines or what kind of immune response this interaction produces, investigators have studied several T. cruzi antigens (Frasch et al. 1991; Franco da Silveira et al. 1992; Taibi et al. 1995; Santori et al. 1996; Pereira-Chioccola et al. 1999). Different murine models have been used for this purpose. Some strains of inbred mice survive acute infection with T. cruzi, while others die (Wrightsman et al. 1982; Andrade et al. 1985; Silva et al. 1992).

In the present paper, the induction of immune response in both $\mathrm{BALB} / \mathrm{c}$ and $\mathrm{C} 57 \mathrm{Bl} / 6$ mice immunized with CRA and FRA recombinant antigens of T. cruzi challenged with the $\mathrm{Y}$ strain of the parasite was investigated. The analysis of the humoral immune response revealed that both strains of challenged mice were able to induce high levels of $\operatorname{IgG} 1, \operatorname{IgG} 2 \mathrm{a}, \operatorname{IgG} 2 \mathrm{~b}$ and $\operatorname{IgG} 3$ in the initial phase of the infection. FRA-immunized $\mathrm{C} 57 \mathrm{BL} / 6$ mice produced only the IgG2b isotype. However, high levels of all isotypes were observed at 30 d.p.i. only with CRA-immunized C57BL/6 mice. Since IgG1 and $\operatorname{IgG} 2 \mathrm{~b}$ are associated with $\mathrm{Th} 2$ and $\operatorname{IgG} 2 \mathrm{a}$ and $\mathrm{IgG} 3$ are associated with Th1 responses, the lack of detectable amounts of parasite-specific antibodies could be due to down-regulation of $\mathrm{T}$ and $\mathrm{B}$ cell responses in these animals resulting from IL-10 and IFN- $\gamma$ produced by trypanosome-specific regulatory cells. In the current study, IL-10 and IFN- $\gamma$ production were observed in both strains of mice. These findings may explain the lack of detectable amounts of antibodies.

It is well established that the acute phase of murine $T$. cruzi infection is initially associated with polyclonal activation. This activation is basically characterized by an intensive B cells proliferation and is not specific to parasite antigens (Minoprio et al. 1988). On the other hand, the differentiation of $\mathrm{B}$ cells is very efficiently stimulated when an antigen is presented in a repetitive rigid form, such as that found on the surface of infectious agents (Zinkernagel and Hengartner 2001). CRA and FRA present repetitive structures and were capable of inducing specific antibodies in BALB/c and $\mathrm{C} 57 \mathrm{BL} / 6$ mice even in the absence of $T$. cruzi infection (Pereira et al. 2003a, 2003b). In the present paper, although antibodies involved in the elimination of the parasites, as reported by Pereira et al. (2003a, 2003b), were detected; and despite the survival of a significant number of immunized infected mice when compared with the control group, the humoral immune response was not enough to provide full protection against $T$. cruzi at 30 d.p.i.

The acute phase of $T$. cruzi experimental infection is also characterized by severe immune supression of $\mathrm{T}$ and $\mathrm{B}$ cells to mitogens and to parasite antigens, with partial restoration of the immune response in the early chronic phase (Curotto de Lafaille et al. 1990). These investigators showed that $T$. cruzi-specific proliferative responses of $\mathrm{T}$ cells can be detected in lymph nodes throughout the course of the infection. In our report, cellular proliferation was minimal in both strains of mice immunized with CRA and FRA. The impaired immunological response of acutely infected mice may be partially due to the absence or marked reduction of responder and/or accessory $\mathrm{T}$ lymphocytes. According to Motrán et al. (1996) the deactivation of accessory T cells during intracellular infection by $T$. cruzi could justify the supression caused by this parasite. Deactivation may occur due to down-regulation of key molecules involved in T-cell activation and proliferation, induction of autoinhibitory cytokines such as IL-10 and the transformation of growth factor $\beta$ (TGF- $\beta$ ) or impaired secretion of monocyte derived factors involved in costimulatory signals (Motrán et al. 1996).

In the present trial, high levels of IFN- $\gamma$ were produced by both mouse strains when speen cells were stimulated in vitro with CRA or FRA recombinant antigens, although a proliferative response was not detectable. Previously reported studies showed that IFN- $\gamma$ has been most closely associated with host resistance during the acute phase of infection (Vespa et al. 1994; Silva et al. 1995; Cardillo et al. 1996). MuñozFernández et al. (1992) suggest that IFN- $\gamma$ and TNF- $\alpha$, secreted by $T$. cruzi-immune $T$ cells, are involved in the activation of the trypanocidal activity of mouse macrophages through an NO-dependent mechanism. In the present paper, the production of IFN- $\gamma$ and TNF- $\alpha$ did not attain appropriate levels to control infection against T. cruzi. Quantification of bloodstream trypomastigotes showed differences in the parasite burden between the two mouse strains. Parasitemia was lower in CRA- or FRA- immunized C57BL/6 than in BALB/c mice. These results indicate that the interplay between host and parasite genetic differences may influence the outcome of a mouse infection with $T$. cruzi.

The above mentioned differences between C57BL/6 and $\mathrm{BALB} / \mathrm{c}$ mice were not surprinsing. However, the survival rate (Table 1) was unexpectedly high in CRAor FRA-immunized BALB/c mice. This finding suggest that CRA and FRA antigens were able to induce an efficient protective response, mainly in BALB/c mice, considered to be a susceptible mouse strain. Survival 
rates of $60 \%$ and $83.3 \%$ were detected for CRAimmunized BALB/c and for CRA-immunized C57BL/6 -mice, respectively. FRA-immunized BALB/c mice had a survival rate of $50 \%$, while no significant survival rate was observed in $\mathrm{C} 57 \mathrm{BL} / 6$. It is likely that enhanced resistance, as measured by an increased survival rate, may be associated with synthesis of IFN- $\gamma$. It has been well demonstrated that the protective response is more frequently associated with a Th1 cytokine profile (Miller et al. 1996).

It is possible that the immunization schedule used with CRA and FRA antigens did not induce significant levels of protective response against a lethal challenge with the parasite. It has been demonstrated that IL-10 is associated with susceptibility to T. cruzi infection (Silva et al. 1992) and the treatment of IL-10 KO and WT mice with recombinant IL-10 results in increased parasitemia (Abrahamsohn et al. 1996). In the current trial, the levels of IL-10 were similar between experimental and control groups. This may have been enough to inhibit the action of IFN- $\gamma$. One of the alternatives to induce the immune protection could be the in vivo administration of IFN- $\gamma$ or IL-12 in association with CRA or FRA antigens. In vivo administration of recombinant IFN- $\gamma$ induces macrophage activation and prevents acute disease, immune supression, and death in mice experimentally infected with T. cruzi (Reed 1988). Furthermore, interleukin 12 acts directly on $\mathrm{CD}^{+}{ }^{+} \mathrm{T}$ cells to enhance priming for IFN-gamma production (Seder et al. 1993) and acts to control parasite replication during acute infection of mice (Aliberti et al. 1996). Thus, different strategies in the immunization of mice, mainly with CRA, could generate a more efficient immune response.

The present results corroborate the idea of the use of IFN- $\gamma$ cytokine as a vaccine adjuvant and provide new insights for the development of strategies for beneficial endogenous immune response and disease treatment. Although immunization with CRA or FRA antigens has failed to produce complete immunity, we are currently attempting to design other vaccination protocols to improve protection. The association of CRA and FRA antigens with recombinant IFN- $\gamma$ could be evaluated in the future.

Acknowledgements We are grateful to Roni Evencio Araújo for his technical assistance. This investigation was supported by Fundação Oswaldo Cruz (Centro de Pesquisas Aggeu Magalhães and Biomanguinhos) and Conselho Nacional de Desenvolvimento Científico e Tecnológico (CNPq). This research was partially supported by Bio-Manguinhos/FIOCRUZ and CNPq.

\section{References}

Abrahamsohn IA, Coffman RL (1995) Cytokine and nitric oxide regulation regulation of the immunosuppression in Trypanosoma cruzi infection. J Immunol 155:3955-3963
Abrahamsohn IA, Coffman RL (1996) Trypanosoma cruzi: IL-10, TNF, IFN- $\gamma$, and IL-12 regulate innate and acquired immunity to infection. Exp Parasitol 84:231-244

Aliberti JCS, Cardoso MAG, Martins GA, Gazzinelli RT, Vieira LQ, Silva JS (1996) Interleukin-12 mediates resistance to Trypanosoma cruzi in mice and is produced by murine macrophages in response to live trypomastigotes. Infect Immunol 64(6):19611967

Andrade V, Barral-Neto M, Andrade SG, Magalhães JB (1985) Aspectos imunológicos da infecção de seis linhagens isogênicas de camundongos por três diferentes cepas do Trypanosoma cruzi. Mem Inst Oswaldo Cruz 80(2):203-211

Araújo FG, Helman B, Tighe L (1984) Antigens of Trypanosoma cruzi detected by different classses and subclasses of antibodies. Trans R Soc Trop Med Hyg 78:672-677

Brener Z (1962) Therapeutic activity and criterion of cure in mice experimentally infected with Trypanosoma cruzi. Rev Inst Med Trop São Paulo 4:389-396

Brenner Z, Krettli AU (1990) Immunology of Chagas disease. In: Wyler DJ (eds) Modern parasite biology-celullar, immunological, and molecular aspects. Freeman Company, New York, pp 247-261

Brodskyn CI, Silva AMM, Takehara HA, Mota I (1989) IgG subclasses responsible for immune clearance in mice infected with Trypanosoma cruzi. Immunol Cell Biol 67:343-348

Cardillo F, Voltarelli JC, Reed SG, Silva JS (1996) Regulation of Trypanosoma cruzi infection in mice by gamma interferon and interleukin 10: role of NK cells. Infect Immunol 64(1):128-134

Curotto de Lafaille MA, Barbosa de Oliveira LC, Lima GCA, Abrahamsohn IA (1990) Trypanosoma cruzi: maintenance of parasite-specific $\mathrm{T}$ cell reponses in lymph nodes during the acute phase of the infection. Exp Parasitol 70:164-174

Franco da Silveira J (1992) Trypanosoma cruzi recombinant antigens for serodiagnosis. In: Wendel S, Brener B, Camargo ME, Rasser A (eds) Chagas disease (American Trypanosomiasis): its impact on transfusion and clinical medicine. International Society of Blood Transfusion, SP, pp 207-217

Frasch ACC, Cazzullo JJ, Aslund L, Petterson U (1991) Comparison of genes encoding Trypanosoma cruzi antigens. Parasitol Today 7:148 -151

Gazzinelli RT, Oswald IP, James SL, Sher A (1992) IL-10 inhibits parasite killing and nitrogen oxide production by IFN- $\gamma$-activated macrophages. J Immunol 148(6):1792-1796

Gomes YM (1997) PCR and sero-diagnosis of chronic Chagas' disease. Biotecnological advances. Appl Biochem Biotechnol 66:107119

Gomes YM, Nakazawa MN, Abath FGC, Minoprio P, Vouldoukis I, Monjour L (1999) Partial protection of mice against Trypanosoma cruzi after immunization with $\mathrm{TcY}$ antigenic preparation. Mem Inst Oswaldo Cruz 94:167-172

Jankovic D, Sher A, Yap G (2001) Th1/Th2 effector choice in parasitic infection: decision making by committe. Curr Opin Immunol 13:403-409

Kierszenbaum F (1981) On evasion of Trypanosoma cruzi from host immune response. Lymphoproliferative responses to trypanosomal antigens during acute and chronic experimental Chagas' disease. Immunology 44:641-648

Kierszenbaum F, Hayes MM (1980) Evaluation of lymphocyte responsiveness to polyclonal activators during acute and chronic experimental Trypanosoma cruzi infection. Am J Trop Med Hyg 29(4):708-710

Krieger MA, Almeida E, Oelemann W, Lafaille JJ, Pereira JB, Carvalho MR, Goldenberg S (1992) Use of recombinant antigens for the accurate immunodiagnosis of Chagas'disease. Am J Trop Med Hyg 46(4):427-434

Millar AE, Kahn SJ (2000) The SA85-1.1 protein of the Trypanosoma cruzi trans-sialidase superfamily is a dominant T-cell antigen. Infect Immunol 68(6):3574-3580 
Miller MJ, Wrightsman RA, Manning JE (1996) Trypanosoma cruzi: protective immunity in mice immunized with paraflagellar rod proteins is associated with a T-helper type 1 response. Exp Parasitol 84:156-167

Minoprio PM, Eisen H, Forni L, D'Imperio Lima MR, Joskowicz M, Coutinho A (1986) Polyclonal lymphocyte responses to murine T. cruzi infection. I - Quantitation of both T- and B-cell responses. Scand J Immunol 24:661-668

Minoprio P, Burlen O, Pereira P, Guilbert B, Andrade L, Hontebeyrie-Joskowicz M, Coutinho A (1988) Most B cells in acute Trypanosoma cruzi infection lack parasite specificity. Scand J Immunol 28:553-561

Motran C, Gruppi A, Vullo CM, Pistoresi-Palencia MC, Serra HM (1996) Involvement of acessory cells in the Trypanosoma cruziinduced inhibition of the polyclonal response of T lymphocytes. Parasite Immunol 18:43-48

Muñoz-Fernández MA, Fernández MA, Fresno M (1992) Synergism between tumor necrosis factor- $\alpha$ and interferon- $\gamma$ on macrophage activation for the killing of intracellular Trypanosoma cruzi through a nitric oxide-dependent mechanism. Eur J Immunol 22:301-307

Nabors GS, Tarleton RL (1991) Differential control of IFN- $\gamma$ and IL-2 production during Trypanosoma cruzi infection. J Immunol 146(10):3591-3598

Pereira VRA, Lorena VMB, Nakazawa M, Galvão da Silva AP, Montarroyos U, Correa-Oliveira R, Gomes YM (2003a) Evaluation of immune response in $\mathrm{C} 57 \mathrm{Bl} / 6$ mice immunized with CRA and FRA recombinant antigens of Trypanosoma cruzi. Rev Soc Bras Med Trop 36(4):435-440

Pereira VRA, Lorena VMB, Verçosa AFA, Galvão da Silva AP, Silva ED, Ferreira AGP, Montarroyos U, Gomes YM (2003b) Antibody isotype responses in BALB/c mice immunized with the cytoplasmic repetitive antigen and flagellar repetitive antigen recombinant antigens of Trypanosoma cruzi. Mem Inst Oswaldo Cruz 98(6):823-825

Pereira VRA, Lorena VMB, Galvão da Silva AP, Coutinho EM, Miranda P, Silva ED, Ferreira AGP, Krieger MA, Goldenberg S, Soares MBP, Correa-Oliveira R, Gomes YM (2004) Immunization with cytoplasmic repetitive antigen and flagellar repetitive antigen of Trypanosoma cruzi stimulates a cellular immune response in mice. Parasitology 129(5):563-570

Pereira-Chioccola VL, Costa F, Ribeirão M, Soares IS, Arena F, Schenkman S, Rodrigues MM (1999). Comparison of antibody and protective immune responses against Trypanosoma cruzi infection elicited by immunization with a parasite antigen delivered as naked DNA or recombinant protein. Parasite Immunol 21:103-110

Powell MR, Wassom DL (1993) Host genetics and resistance to acute Trypanosoma cruzi infection in mice. I. Antibody isotype profiles. Parasite Immunol 15:215-221

Ramos C, Schädtler-Siwon I, Ortiz-Ortiz L (1979) Supressor cells present in the spleens of Trypanosoma cruzi-infected mice. J Immunol 122(4):1243-1247

Reed SG (1988) In vivo administration of recombinant IFN- $\gamma$ induces macrophage activation, and prevents acute disease, immune supression, and death in experimental Trypanosoma cruzi infections. J Immunol 140:4342-4347
Rottenberg ME, Bakhiet M, Olsson T, Kristensson TM, Hans W, Örn A (1993) Differential susceptibilities of mice genomically deleted of CD4 and CD8 to infections with Typanosoma cruzi or Trypanosoma brucei. Infect Immunol 61(12):5129-5133

Santori FR, Paranhos-Bacalla GS, Silveira JF, Yamauchi LM, Araya JE, Yoshida N (1996) A recombinant protein based on the Trypanosoma cruzi metacyclic Trypomastigote 82-kilodalton antigen that induces on effective imune response to acute infection. Infect Immunol 64:1093-1099

Schnapp AR, Eickhoff CS, Sizemore D, Curtis III R, Hoft DF (2002) Cruzipain induces both mucosal and systemic protection against Trypanosoma cruzi in mice. Infect Immun 70(9):50655074

Seder R, Gazzinelli R, Sher A, Paul WE (1993) Interleukin 12 acts directly on $\mathrm{CD}^{+}{ }^{+} \mathrm{T}$ cells to enhance priming for interferon $\gamma$ production and diminishes interleukin 4 inhibition of such priming. Proc Natl Acad Sci USA 90:10188-10192

Sher A, Coffman RL (1992) Regulation of immunity to parasites by $\mathrm{T}$ cells and $\mathrm{T}$ cell-derived cytokines. Annu Rev Immunol 10:385-409

Silva JS, Morryssey PJ, Grabstein KH, Mohler KM, Anderson D, Reed SG (1992) Interleukin-10 and interferon- $\gamma$ regulation of experimental Trypanosoma cruzi infection. J Exp Med 175:169174

Silva JS, Vespa GNR, Cardoso MAG, Aliberti JCS, Cunha FQ (1995) Tumor necrosis factor alpha mediates resistance to Trypanosoma cruzi infection in mice by inducing nitric oxide production in infected gamma-interferon-activated macrophages. Infect Immunol 63(12):4862-4867

Taibi A, Espinoza AG, Ouaissi A (1995) Trypanosoma cruzi analysis of cellular and humoral response against a protective recombinant antigen during experimental Chagas' disease. Immunol Lett 48:193-200

Takehara HA, Perini A, Silva MH, Mota I (1981) Trypanosoma cruzi: role of different antibody classes in protection against infection in the mouse. Exp Parasitol 52:137-146

Vespa GNR, Cunha FQ, Silva JS (1994) Nitric oxide is involved in control of Trypanosoma cruzi-induced parasitemia and directly kills the parasite in vitro. Infect Immunol 62(11):51775182

WHO- World Health Organization (2002) The World Health Report, Geneva

Wrighstsman R, Krassner S, Watson J (1982) Genetic control of responses to Trypanosoma cruzi in mice: multiple genes influencing parasitemia and survival. Infect Immunol 36(2):637-44

Zambrano-Villa S, Rosales-Borjas D, Carrero JC, Ortiz-Ortiz L (2002) How protozoan parasites evade the immune response. Trends Parasitol 18(6):272-278

Zinkernagel RM (2000). Localization dose and time antigens determine immune reactivity. Sem Immunol 12:163-171

Zinkernagel RM, Hengartner H (2001) Regulation of the immune response by antigen. Science 293(5528):251-253 